\title{
GOMMENT
}

\section{A PROPOSED MODEL OF THE SOVEREIGN/ PROPRIETARY DISTINCTION}

\author{
Teresa Gillent
}

The United States Supreme Court has suggested that governments that act as "sovereigns" are or should be subject to different constitutional standards than governments that act as "proprietors." This sovereign/proprietary distinction has befuddled some commentators ${ }^{2}$ and has been criticized by others; ${ }^{3}$ few authorities off the Court have embraced it, ${ }^{4}$ and commentary on the distinction reflects a vague hope that the Court will abandon it. ${ }^{5}$ This, however, has not happened.

† B.A. 1977, University of Rochester, M.A. 1981, University of Chicago, J.D. Candidate, 1985, University of Pennsylvania. The author wrote this Comment while a student at the University of Pennsylvania Law School.

1 The distinction has long existed in the areas of municipal tort liability and sovereign immunity. See W. Prosser, HaNDBook of THE LAW of TORTS $\S 131$, at 97787 (4th ed. 1971). For other areas in which the distinction may be applicable, see Wells \& Hellerstein, The Governmental-Proprietary Distinction in Constitutional Law, 66 VA. L. REV. 1073, 1073-74 n.9 (1980). This Comment confines itself to constitutional law.

2 See, e.g., Wells \& Hellerstein, supra note 1, which is the only major commentary on the recent use of the distinction in constitutional law. The authors express ambivalence about the distinction's merit. See id. at 1136-39.

${ }^{3}$ See, e.g., Kreimer, Allocational Sanctions: The Problem of Negative Rights in a Positive State, 132 U. PA. L. Rev. 1293, 1317-24 (1984); Varat, State 'Citizenship' and Interstate Equality, 48 U. CHI. L. REv. 487, 505-07 (1981); Note, Proprietary Powers: A New Tool for the States?, 31 U. Miami L. Rev. 729 (1977); Note, State Market Activity Exempt from Commerce Clause Review, 27 WAYNE L. REv. 1575, 1599 (1981); see also L. TRIBE, AMERICAN Constitutional LAW § 6-10, at 336-38 (1978) (criticizing the distinction raised in Hughes v.. Alexandria Scrap Corp., 426 U.S. 794 (1976)). Interestingly, Professor Tribe argued the case for the appellants before the Supreme Court in White v. Massachusetts Council of Constr. Employers, 460 U.S. 204 (1983), a case in which the Court relied heavily on Alexandria Scrap.

Sixty years ago the Court itself criticized the distinction as "utterly irrelevant to the standards imposed under the Constitution." Trenton v. New Jersey, 262 U.S. 182, 191-92 (1923).

- Only a handful of lower courts have relied upon the distinction. See, e.g., Smith v. Department of Agriculture, 630 F.2d 1081 (5th Cir. 1980), cert. denied, 452 U.S. 910 (1981); Gould, Inc. v. Wisconsin Dep't of Indus., Labor \& Human Relations, 576 F. Supp. 1290 (W.D. Wis. 1983), rev'd in part, Nos. 84-1115, 84-2075 (7th Cir. Dec. 18, 1984); Transport Limousine, Inc. v. Port Auth., 571 F. Supp. 576 (E.D.N.Y. 1983).

S See, e.g, Wells \& Hellerstein, supra note 1, at 1139 ("The governmental-proprietary distinction, however, despite its longevity, does not play such a pervasive role 
Unfortunately, the Court has never defined the terms sovereign and proprietor, an omission that suggests the problematic nature of the Court's distinction. When labeling a governmental entity a proprietor or "market participant"-a term it treats as synonymous with proprietor-the Court appears to mean that the entity is engaged in buying or selling a good or service directly to or from the private sector. ${ }^{\circ}$ The Court has applied this label to a local government that contracts with builders to construct public works; ${ }^{7}$ to a local government that operates a public bus system; ${ }^{8}$ to a state government that operates a cement plant and sells cement to the public; ${ }^{9}$ and to a state government that pays junk dealers for abandoned car scraps. ${ }^{10}$ The Court recently split over whether a public school board was a sovereign or nonsovereign, with a plurality voting for the former. ${ }^{11}$

Conversely, when describing a governmental entity as a sovereign, the Court appears to refer: to a government that is either taxing or regulating the activity of private parties. ${ }^{12}$ For example the Court has labeled as sovereign a state that required that all produce grown in the state be packed before shipment ${ }^{13}$ and a state that required in-state gas producers to supply domestic needs before piping the surplus to other states. ${ }^{14}$

Whether a court treats a governmental entity as a proprietor or sovereign is important, for in certain areas of the law nongovernmental entities, of which a governmental entity acting as a proprietor would be one, are subject to different standards than are governmental entities. In some areas, for instance, governmental entities are immune from liability for actions for which nongovernmental entities are liable. Tort law, which recognizes the defense of sovereign immunity, is one example. ${ }^{15}$ In other areas, however, legal prohibitions are directed specifi-

[i.e., like the term "ownership"], and, if the case against it were strong enough, a persuasive argument could be made for abandoning it altogether.").

- Justice Stevens suggested that the state may even create the market itself. See Hughes v. Alexandria Scrap Corp., 426 U.S. 794, 815 (1976) (Stevens, J., concurring).

7 See, e.g., United Bldg. and Constr. Trades Council v. Mayor of Camden, 104 S. Ct. 1020 (1984); White v. Massachusetts Council of Constr. Employers, 460 U.S. 204 (1983).

${ }^{8}$ See Lehman v. City of Shaker Heights, 418 U.S. 298 (1974).

- See Reeves, Inc. v. Stake, 447 U.S. 429 (1980).

10 See Hughes v. Alexandria Scrap Corp., 426 U.S. 794 (1976).

11 See Board of Educ. v. Pico, 457 U.S. 853 (1982) (plurality opinion). The language was not quite this explicit. See infra text accompanying notes 56-65.

${ }_{12}$ See Hughes v. Alexandria Scrap Corp., 426 U.S. 794, 806 (1976).

13 See Pike v. Bruce Church, Inc., 397 U.S. 137 (1970), cited in Hughes v. Alexandria Scrap Corp., 426 U.S. 794, 805 (1976).

14 See Pennsylvania v. West Virginia, 262 U.S. 553 (1923), cited in Hughes v. Alexandria Scrap Corp., 426 U.S. 794, 806 (1976).

$15 \mathrm{~W}$. Prosser, supra note $1, \S 131$, at $977-87$. 
cally at governments and are not applicable to private actors. The commands of the first amendment and the commerce clause are examples of such prohibitions. The result of these differences is that a court that labels a governmental entity as a proprietor will often subject that entity's actions to different legal standards than will a court that labels such an entity as a sovereign.

The distinction reflects the Constitution's concern with outlining and limiting the powers of government while leaving individual freedom unrestricted. As Professor Stone has stated, "Where an ordinary mortal is concerned, we can discern a value in preserving a sphere, free from state influence, in which he or she may be arbitrary, capricious, or prejudicial."16 Governments, the Constitution tells us, ought not to be arbitrary, capricious, or prejudicial. They do not benefit from the intrinsic value of the freedom to be capricious. Moreover, governments have extraordinary powers to coerce individuals and to infringe upon their liberty. The Constitution attempts to limit these governmental powers.

One can also view the Constitution as an attempt to limit the relative advantages and capacities of the public and private sectors. It enables the government to intervene in the market when the private sector might become overwhelming or conflict with the needs of the nation. ${ }^{17}$ However, it also attempts to limit the power of the public sector in areas where it has special advantages-mostly in noneconomic areas.

If the sovereign/proprietary distinction represents an accurate view of the functions of governments, it may be a useful analytical tool in certain types of cases. However, the Court's use of the distinction has been neither thoughtful nor principled. Rather, the Court has invoked it sporadically and without any attempt to explain its underlying rationale or to outline any limiting principles.

Proceeding on the assumption that the distinction may be helpful in certain types of cases, this Comment proposes a model for distinguishing between governments that act as sovereigns and those that act as proprietors. The first Part reviews the cases in which the Supreme Court has either embraced or rejected the distinction. Part II discusses the advantages and disadvantages of the distinction and demonstrates the Court's unprincipled use of it. Part III proposes a method for distinguishing sovereign governmental activity from proprietary governmental activity. The Part then re-examines the cases discussed in Part I

10 Stone, Corporate Vices and Corporate Virtues: Do Public/Private Distinctions Matter?, 130 U. PA. L. REv. 1441, 1489 (1982).

${ }_{17}$ Examples may be found among the powers granted to Congress by article I of the Constitution, especially power to regulate interstate commerce. 
in light of the proposed analysis. The Comment concludes that the sovereign/proprietary distinction, if used in a principled way, can be useful in commerce clause cases but warns that its major shortcoming is that its use is limited to those cases.

\section{The Court's Distinction}

The Supreme Court's use of the sovereign/proprietary distinction has been ad hoc and confusing. ${ }^{18}$ The Court has not always invoked the distinction in cases in which it might have, ${ }^{10}$ and, as a result, it is unclear what governmental activity falls under which category. The Court has used the distinction most consistently in a handful of commerce clause cases. This makes sense because a characterization of the government's economic function can be helpful when the governmental activity being challenged is economic in nature, as in the commerce clause cases. Various members of the Court have argued that the distinction should also be used in non-commerce clause cases; however, reliance on the distinction is less helpful when noneconomic rights are involved, and the Court has been less sure in its use of the distinction in that context.

\section{A. The Economic Realm: The Commerce Clause}

The Supreme Court cases applying the sovereign/proprietary distinction to governmental activity challenged under the commerce clause have been decided under the "dormant" commerce clause doctrine. According to this doctrine, the Constitution's grant to Congress of power to regulate interstate commerce implies that a state is not free to act in a manner that imposes improper burdens on interstate commerce. ${ }^{20}$ For example the dormant commerce clause limits a state's ability to impose restrictions on trucks traveling on roadways in that state. ${ }^{21}$

The Supreme Court has held in many cases that state governments acting as market participants are exempt from the restrictions imposed by the dormant commerce clause. Hughes v. Alexandria Scrap

18 Symptomatic of this is the Court's recent formulation of a "quasi-sovereign" category. See Snapp, Inc. v. Puerto Rico, 458 U.S. 592, 600-08 (1982).

${ }_{10}$ For example the Court has not invoked the distinction in cases dealing with the need for governmental efficiency in the management of property or the provision of services. See, e.g., United States Postal Serv. v. Council of Greenburgh Civic Ass'ns, 453 U.S. 114 (1981).

${ }^{20}$ See L. TRIBE, supra note $3, \S \S 6-1$ to $6-12$, at 319-412.

21 See, e.g., Raymond Motor Transp., Inc. v. Rice, 434 U.S. 429 (1978); Bibb v. Navajo Freight Lines, Inc., 359 U.S. 520 (1959). 
Corp., ${ }^{22}$ the first of these cases, involved a Maryland program for dealing with the problem of abandoned automobiles. The state offered scrap processors a bounty for the destruction of any abandoned automobile that had been titled in Maryland. Several years after the program was established, Maryland, seeking to decrease state expenditures for the destruction of automobiles abandoned in other states, changed the program by imposing documentation requirements on non-Maryland processors more stringent than those applicable to domestic processors. ${ }^{23}$ The federal district court ruled that the amended program violated the commerce clause and the equal protection rights of out-ofstate processors, ${ }^{24}$ and the Supreme Court reversed.

The Court admitted that "the practical effect of the amendment ... . was that the movement of hulks in interstate commerce was reduced,"25 but it rejected the argument "that every action by a State that has the effect of reducing in some manner the flow of goods in interstate commerce is potentially an impermissible burden." ${ }^{\text {"26 }}$ Rather, the Court stated that the regulation did not even fall within the boundaries of the commerce clause: "Maryland has not sought to prohibit the flow of hulks, or to regulate the conditions under which it may occur. Instead, it has entered into the market itself to bid up their price."22 The traditional commerce clause inquiry was thus not required. "Nothing in the purposes animating the Commerce Clause prohibits a State, in the absence of congressional action, from participating in the market and exercising the right to favor its own citizens . . . ."28

Four years later the Court relied on Alexandria Scrap in Reeves, Inc. v. Stake, ${ }^{2 \theta}$ a case in which it held that a South Dakota restriction on the sale of cement produced by a state-operated cement plant to nonresidents did not run afoul of the commerce clause. The state had built the plant in response to regional cement shortages, ${ }^{30}$ and for over

22426 U.S. 794 (1976).

23 See id. at 804-05.

24 Alexandria Scrap Corp. v. Hughes, 391 F. Supp. 46, 58, 63 (D. Md. 1975), rev'd, 426 U.S. 794 (1976).

${ }^{25}$ Alexandria Scrap, 426 U.S. at 803 (footnote omitted).

$28 \mathrm{Id}$. at 805.

${ }^{27}$ Id. at 806 .

${ }^{28}$ Id. at 810 (footnotes omitted). Justice Brennan, in a dissent joined by Justices Marshall and White, questioned the existence of a state's "right" to favor its own citizens, especially in light of prior commerce clause cases suggesting that such favoritism was prohibited. See id. at 822-23 (Brennan, J., dissenting). He also asserted that prior cases upholding restrictive state purchasing statutes had done so only when the state was purchasing for its own use, in contrast with the case at hand, in which the state was acting as "one link in the chain of interstate commerce." Id. at 824.

29447 U.S. 429 (1980).

so Id. at 430 . 
fifty years it had produced cement that was sold to in-state and out-ofstate buyers alike. But by 1978 the plant was no longer able to fill all the orders it received, leading the State Cement Commission to reaffirm " its policy of supplying all South Dakota customers first and to honor all contract commitments, with the remaining volume allocated on a first come, first served basis.' "31 The federal district court concluded that this practice was contrary to the national free market envisioned by the commerce clause, ${ }^{32}$ but the Court of Appeals for the Eighth Circuit disagreed and reversed; the Supreme Court upheld the reversal. The Court stated,

The basic distinction drawn in Alexandria Scrap between States as market participants and States as market regulators makes good sense and sound law. . . . There is no indication of a constitutional plan to limit the ability of the States themselves to operate freely in the free market. . . .

[S]tate proprietary activities may be, and often are, burdened with the same restrictions imposed on private market participants. Evenhandedness suggests that, when acting as proprietors, States should similarly share existing freedoms from federal constraints, including the inherent limits of the Commerce Clause. ${ }^{33}$

Because the Court found that South Dakota "unquestionably" was a market participant in this case, it held that the state's activity was exempt from commerce clause scrutiny. ${ }^{34}$

The Court relied heavily on Alexandria Scrap and Reeves in White v. Massachusetts Council of Construction Employers, ${ }^{35}$ its most recent decision involving the commerce clause and the sovereign/proprietary distinction. In White an organization of builders challenged a Boston ordinance that required that at least one-half of employees of all

s1 Id. at 432-33 (quoting Report of State Cement Commission 13 (1920)).

s2 See id. at 433 .

ss Id. at 436-39 (footnote and citations omitted).

s4 See id. at 440 . Justice Powell, in a dissenting opinion joined by Justices Brennan, White, and Stevens, argued that the majority had misused the Alexandria Scrap analysis. The inquiry, he said, was not simply whether the state was entering the market, but whether that activity "constituted an impermissible burden on interstate commerce." Id. at 451 (Powell, J., dissenting). He asserted that the second part of the inquiry in Alexandria Scrap had determined that the Maryland prohibition had not completely halted the flow of car hulks in interstate commerce and that, consequently, the Maryland program was not barred by the commerce clause. Here, however, the South Dakota policy completely shut off interstate trade. Id. at 452 . Thus, Powell argued, it violated the commerce clause.

35 460 U.S. 204 (1983). 
contractors to whom city construction contracts were awarded be Boston residents. ${ }^{36}$

The Supreme Court reversed the Supreme Judicial Court of Massachusetts's decision that the ordinance was unconstitutional, ${ }^{\mathbf{3 7}}$ declaring, "[W]hen a state or local government enters the market as a participant it is not subject to the restraints of the Commerce Clause."38 The "single inquiry" used by the Court was "whether the challenged program constituted direct state participation in the market." "s9 The Court stated that "[i]f the city is a market participant, then the Commerce Clause establishes no barrier"40 to the ordinance. Concluding that in this case the city was acting as a proprietor, ${ }^{41}$ the Court did not even enter into an analysis of the constitutionality of the ordinance. ${ }^{42}$

${ }^{38}$ See id. at 206.

37 The Massachusetts court held that the commerce clause prohibited such regulations. See id. at 206 (citing Massachusetts Council of Constr. Employers v. Mayor of Boston, 384 Mass. 466, 425 N.E.2d 346 (1981)). Using standard commerce clause analysis, it found that the ordinance would have a significant impact on the employment of out-of-state residents and that the preference for state residents was a broadsweeping one not targeted at the legitimate interests asserted by the city. See id. at 208 (citing Massachusetts Council, 384 Mass. at 479, 425 N.E.2d at 354-55).

${ }_{38}$ White, 460 U.S. at 208.

so Id. (quoting Reeves, Inc. v. Stake, 447 U.S. 429, 436 n.7 (1980)).

to $I d$. at 210.

42 See id. at 215. The Court also stated that "[i]nsofar as the mayor's executive order was applied to projects funded in part with funds obtained from the federal programs described above, the order was affirmatively sanctioned by the pertinent regulations of those programs." Id.

12 Three of the four Justices who had dissented in Reeves joined the majority in White, while Justice Blackmun, who wrote the Court's opinion in Reeves, dissented in White. Justice Blackmun argued that Alexandria Scrap and Reeves had been concerned with "ensuring that the States enjoy "the long recognized right of trader or manufacturer, engaged in an entirely private business, freely to exercise his own independent discretion as to parties with whom he will deal." "White, 460 U.S. at 217 (Blackmun, J., dissenting) (quoting Reeves, 447 U.S. at 438-39). The Boston ordinance, however, "directly restricts the ability of private employers to hire nonresidents, and thereby curtail nonresidents' access to jobs with private employers." Id. This type of preference "[is] not immune . . . solely because the city has imposed [it] as [a] condition[] to its contracts with private employers." Id.

Justice Blackmun proposed a modified purpose analysis, based upon the principles of Reeves, for distinguishing between a state acting as a sovereign and one acting as a proprietor. Applying this analysis to the cases, he argued that Reeves and Alexandria Scrap "were relatively pure examples of a seller's or purchaser's simply choosing its bargaining partners," whereas White was a case of "a direct attempt to govern private economic relationships." Id. at 218-19. Unfortunately, although his perception of a need to establish limits upon the applicability of the sovereign/proprietary distinction was accurate, Justice Blackmun's attempt to provide such a limit is not very helpful. His focus on whether the action "more closely resembles an attempt to impede trade among private parties," id. at 218 , does not indicate whether he is more concerned with the state's purpose or with the effect of the state's action. The latter seems to be his true concern when he warns that the effect of a requirement limiting trade with out-ofstaters "would be virtually identical" to a market regulation. See id. at 220 .

A more serious problem, however, is that this inquiry does not seem to distinguish 


\section{B. Noneconomic Cases}

\section{Procedural Due Process}

Cafeteria and Restaurant Workers Union $v$. McElroy ${ }^{43}$ was the first case in which the Supreme Court used the sovereign/proprietary distinction. In McElroy an employee of a cafeteria at a federal government weapons plant was dismissed without a hearing because she failed to satisfy certain security requirements. The Court held that the failure to provide a hearing did not violate the due process clause for two reasons: the employee's interest in the job was not sufficiently important and the government's proprietary military capacity gave it unfettered control. ${ }^{44}$ The Court noted, "[T] he governmental function operating here was not the power to regulate or license, as lawmaker, an entire trade or profession, or to control an entire branch of private business,

White from the other cases. Justice Blackmun argued that the legislative schemes attacked in Alexandria Scrap and Reeves were attempts by states to choose their bargaining partners, yet the Boston ordinance at issue in White was arguably a similar effort. Although Justice Blackmun perceived the ordinance as an attempt by Boston to control the hiring policies of private employers, it really was a decision by the city to refuse to deal with firms composed of non-Bostonians. Justice Blackmun's dissent thus fails to provide a satisfactory limitation on the scope of the sovereign/proprietary distinction.

An interesting aspect of Justice Blackmun's dissent is his avoidance of the antitrust issue. He noted that efforts by governments to dictate to a private party with whom she may deal is the "essence of regulation," however, such efforts by private parties, although "viewed with suspicion and closely limited," are not absolutely prohibited. See id. at 218. In a footnote he cited several cases in which attempts to induce trading partners not to deal with other persons were held to violate the antitrust laws. See id. at 219-20 n.4. If one wanted to discourage state and local governments from doing the same thing, the obvious approach would be to bring an antitrust suit against them. However, the state action is immune from federal antitrust law. See Parker v. Brown, 317 U.S. 341 (1943).

The rationale for this immunity is that the commerce clause was not intended

to restrain a state or its officers or agents from activities directed by its legislature. In a dual system of government in which, under the Constitution, the states are sovereign ...., an unexpressed purpose to nullify a state's control over its officers and agents is not lightly to be attributed to Congress.

Id. at $350-51$.

Parker has been widely criticized. See Handler, The Current Attack on the Parker v. Brown State Action Doctrine, 76 Colum. L. Rev. 1, 1 n.3, 3 n.8 (1976). Recently, a federal district court held that when the state is acting as a proprietor, it should not be immune from antitrust suits under the state action exemption. See Limeco, Inc. v. Division of Lime, 546 F. Supp. 868 (N.D. Miss. 1982). This exception was also suggested in Note, The Presumption Alternative to Municipal Antitrust Liability, 51 GEo. WASH. L. REv. 145, 166 (1982). This approach supplies some badly needed consistency to the sovereign/proprietary distinction, and it is unfortunate that Justice Blackmun did not include it in his dissent in White.

4367 U.S. 886 (1961).

14 See id. at 895-96. 
but, rather, as proprietor, to manage the internal operation of an important federal military establishment."

The Court seems to have used the proprietor language here as a descriptive tool in its analysis of the government's interest. The Court did not hold that the government's function or interest was equivalent to that of a private proprietor, although the language is somewhat unclear on this point. The Court first stated that "[i]t has become a settled principle that government employment, in the absence of legislation, can be revoked at the will of the appointing officer," ${ }^{36}$ but it then went on to argue that "state and federal governments, even in the exercise of their internal operations, do not constitutionally have the complete freedom of action enjoyed by a private employer."47

Although the Court has continued to use a functional approach when considering procedural due process claims, it has not invoked $M c$ Elroy's proprietor language in cases in which the government is the employer. ${ }^{48}$

\section{The First Amendment}

Although no majority opinion of the Court has ever relied on the sovereign/proprietary distinction in a first amendment case, plurality, concurring, and dissenting opinions have occasionally advocated its use in this context. Lehman v. City of Shaker Heights ${ }^{49}$ and Board of Education, Island Trees Union Free School District No. 26 v. Pico ${ }^{50}$ provide two examples.

In Shaker Heights the Court upheld an agreement between a city and an advertising company that prohibited political advertising on city transportation vehicles. A plurality of four justices ${ }^{\mathrm{bI}}$ rejected the argument that advertising space in a bus is a public forum and held that, in providing transportation, the city was engaged in a "commercial venture" and was acting in a "proprietary capacity" when it banned the advertisements. ${ }^{52}$

In much the same way that a newspaper or periodical, or

15 Id. at 896 (citation omitted).

48 Id. (citation omitted).

17 Id. at 897-98. For example the Court stated that a state would not have been free to dismiss an employee for reasons that were "patently arbitrary or discriminatory." Id. at 898.

18 See, e.g., Board of Regents v. Roth, 408 U.S. 564 (1972).

19418 U.S. 298 (1974) (plurality opinion).

so 457 U.S. 853 (1982) (plurality opinion). plurality.

81 Justices Blackmun, White, Rehnquist, and Chief Justice Burger formed the

${ }^{82}$ See Shaker Heights, 418 U.S. at 303-04 (plurality opinion). 
even a radio or television station, need not accept every proffer of advertising from the general public, a city transit system has discretion to develop and make reasonable choices concerning the type of advertising that may be displayed on its vehicles. ${ }^{\text {ss }}$

The plurality stated that this was a "managerial decision" not unlike decisions about fares or the location of bus stops and, thus, that the advertising ban did not violate the first amendment. ${ }^{54}$

The plurality then utilized the sovereign/proprietary distinction to permit the city to restrict political expression much as a private bus company could: "[T] rapid, convenient, pleasant and inexpensive service to the commuters of Shaker Heights."

In Pico the Court divided on the issue whether a school board's removal of books from a public library violated the first amendment. The case produced seven opinions, with a judgment that the case be remanded to the district court for further factual findings. A plurality of three Justices, ${ }^{56}$ balancing the students' right to receive information ${ }^{57}$ against the school board's need to determine the content of books for educational purposes, ${ }^{68}$ concluded that if the decisive factor in the school board's decision was an intent to deny the students access to ideas with which the school board disagreed, then the removal would violate the students' first amendment rights. ${ }^{58}$ Two Justices concurred on separate grounds. ${ }^{60}$

ss Id. at 303.

${ }^{54} \mathrm{See} i d$. at 304 . Justice Douglas wrote a separate concurring opinion, emphasizing the constitutional rights of commuters who have no choice but to sit and look at the messages. Douglas relied on his dissent in Public Utils. Comm'n v. Pollak, 343 U.S. 451, 469 (1952), arguing that in both Pollak and Shaker Heights "the viewer or listener is captive." Shaker Heights, 418 U.S. at 307 (Douglas, J., concurring).

ss Id. at 303.

so The plurality consisted of Justices Brennan, Marshall, and Stevens.

s7 See Pico, 457 U.S. at 866-69 (plurality opinion).

88 See id. at 869.

so See id. at 871 .

60 Justice Blackmun wrote a separate opinion concurring in the need for further factual findings. He rejected the plurality's argument that students have a right to receive information in a public library, see id. at 878 (Blackmun, J., concurring in judgment), and concluded that "school officials may not remove books for the purpose of restricting access to the political ideas or social perspectives discussed in them, when that action is motivated simply by the officials' disapproval of the ideas involved," $i d$. at 879-80.

Justice White concurred in the need for further factfinding, but did so on the narrow grounds that the district court had granted summary judgment despite the existence of a material issue of fact. Justice White argued that the Court should not have addressed the difficult first amendment issues raised by the removal of books so long as 
The four Justices who dissented in Pico invoked the sovereign/ proprietary distinction to argue that the school board did not violate the first amendment. Justice Rehnquist, joined by Chief Justice Burger and Justice Powell, argued that the first amendment imposed less rigid constraints on government when it acts in a nonsovereign capacity than when it acts in a sovereign one:61 "[E]xpressive conduct which may not be prohibited by the State as sovereign may be proscribed by the State as property owner;", "actions by the government as educator do not raise the same First Amendment concerns as actions by the government as sovereign." Cas Categorizing the school board's actions as proprietary, Rehnquist concluded that there was no constitutional violation. ${ }^{84}$ Justice O'Connor, in a separate dissenting opinion, found Justice Rehnquist's analysis of the government's "special role as educator" to be persuasive. ${ }^{65}$

In two other first amendment cases, Healy v. James ${ }^{66}$ and Southeastern Promotions, Ltd. $v$. Conrad, ${ }^{67}$ Justice Rehnquist was the only Justice to favor application of the sovereign/proprietary distinction. In Healy, decided during Justice Rehnquist's first Term on the Court, the Court held that a state college's refusal to recognize a campus group violated the first amendment unless it could be shown that the group had refused to comply with campus regulations. ${ }^{68}$ Justice Rehnquist concurred and stated, "I find the implication clear from the Court's opinion that the constitutional limitations on the government's acting as an administrator of a college differ from the limitations on the government's acting as a sovereign to enforce its criminal laws." ${ }^{\text {"69 }} \mathrm{He}$ thus outlined what would become a favorite theme, adding that it was

equally clear that the government in its capacity as employer also differs constitutionally from the government in its capacity as the sovereign executing criminal laws.

. . The government as employer or school administrator may impose upon employees and students reasonable reg-

the reasons for the removal were not elucidated by the factual record. See id. at 883 (White, J., concurring in judgment).

61 See id. at 908 (Rehnquist, J., dissenting).

${ }^{62} \mathrm{Id}$.

63 Id. at 910 .

Be Id. at 920 .

${ }^{65}$ Id. at 921 (O’Connor, J., dissenting).

66408 U.S. 169 (1972).

67 420 U.S. 546 (1975).

68 See Healy, 408 U.S. at 185-94.

${ }^{68}$ Id. at 201 (Rehnquist, J., concurring). 
ulations that would be impermissible if imposed by the government upon all citizens. ${ }^{70}$

In the following Term, the Court held in Southeastern Promotions that a municipal auditorium's refusal to permit a performance of the musical "Hair" violated the first amendment. ${ }^{71}$ The majority reasoned that a municipal auditorium was a public forum and, therefore, that the denial, which was based on the content of the intended performance, was an unconstitutional prior restraint. ${ }^{72}$ In a solo dissenting opinion Justice Rehnquist charged that the Court was ignoring the fact that the government was acting as a manager of property and "not prohibiting or penalizing the expression of views in dramatic form by citizens at large." ${ }^{\text {"7s }}$ As for the standard of review that should be applied to the auditorium's action, he said,

A municipal theater may not be run by municipal authorities as if it were a private theater, free to judge on a content basis alone . . . . But, just as surely, that element of it which is 'theater' ought to be accorded some constitutional recognition along with that element of it which is 'municipal."74

As the above cases suggest, Justice Rehnquist has been the most ardent proponent of incorporating the sovereign/proprietary distinction into first amendment doctrine. This advocacy has continued off the bench, where he has discussed the difficulty of applying a single theory or philosophy of the first amendment to cases in which the governmental role is not that of a sovereign but rather that of a proprietor or employer.

In a 1976 address at Gonzaga Law School, Justice Rehnquist pointed to a case decided that year, Greer $v$. Spock, ${ }^{75}$ as illustrative of the Court's recognition of the sovereign/proprietary distinction in first amendment cases. ${ }^{76}$ The majority in Greer approved military regulations that forbade political speeches and demonstrations at a military base on the grounds that the base's special purpose was to train soldiers and not to serve as a public forum. ${ }^{77}$ Justice Rehnquist, in his address,

70 Id. at 202-03 (Rehnquist, J., concurring) (emphasis added). Thus one distinction appears to be the number of people affected by the government's action.

71 Southeastern Promotions, 420 U.S. at 552.

72 Id.

${ }^{73}$ Id. at 571 (Rehnquist, J., dissenting).

74 Id. at 574-75.

75 424 US. 828 (1976).

28 Rehnquist, The First Amendment: Freedom, Philosophy, and the Law, 12 Gonz. L. REv. 1, 10 (1976).

77 See Greer, 424 U.S. at $837-38$. The Court also held that a regulation that 
argued that "[w]hatever other significance this case may have, it surely stands for the proposition that the government may regulate speech on its own property in ways which it could not do if the regulated speech were on private property."'7s

Justice Rehnquist also argued in the address that the Court had endorsed the distinction in cases in which the government was an employer. As an example, he cited Arnett $v$. Kennedy, ${ }^{79}$ a case in which a divided Court held that the federal government's dismissal of an employee without a pretermination evidentiary hearing did not violate the employee's procedural due process rights when the employee had in reckless disregard of the truth claimed that his supervisor had attempted to bribe a community leader. ${ }^{80}$ Moreover, the Court held that a statute that permits firing a federal employee for such "cause as will promote the efficiency" of a governmental agency is not so overbroad or vague as to improperly chill the exercise of first amendment rights. ${ }^{81}$ Interpreting this decision, Justice Rehnquist noted in his lecture,

Thus, again we see that the Court has treated differently the government as sovereign and lawgiver from the way it treats the government as an employer. . . . After all, if one of the principal reasons for having freedom of expression is the desirability of the electorate being fully informed in order to democratically decide on how it shall be governed, some latitude must be given to the duly elected representatives of that electorate in the implementation of the policies they have chosen ... and it would seem scarcely open to doubt that the policy will be best effectuated by those who do not make unfounded charges about their boss's official conduct. ${ }^{\mathbf{8 2}}$

permitted the base commander to prohibit distribution of literature that he thought constituted " "a clear danger to [military] loyalty, discipline or morale," "id. at 840 (quoting Department of the Army letter, Guidance on Dissent (June 23, 1969)), did not violate the first amendment, see id. at 838-40.

78 Rehnquist, supra note 76, at 11.

79416 U.S. 134 (1974) (plurality opinion).

80 Id. at 163-64.

81 Justice Rehnquist's plurality opinion, joined by two other Justices, held that the statutory provision authorizing the firing of an employee for cause was not so vague or overbroad as to violate the first amendment. See id. at 158-64 (plurality opinion). Justice Powell's concurring opinion, joined by one other justice, agreed with the plurality that the provision was "neither unconstitutionally vague nor overbroad." Id. at 164 (Powell, J., concurring).

82 Rehnquist, supra note 76, at 12. 


\section{Privileges and Immunities Clause}

Last Term, the Supreme Court refused to adopt the sovereign/ proprietary distinction in a privileges and immunities clause case. At issue in United Building and Construction Trades Council v. Mayor of Camden ${ }^{83}$ was a Camden, New Jersey ordinance that closely resembled the Boston ordinance approved in White-it required that at least forty percent of the employees of contractors working on Camden construction projects be residents of the city. The Supreme Court of New Jersey declined to apply the privileges and immunities clause because the ordinance was not a state regulation. ${ }^{84}$ After that decision, the United States Supreme Court decided White, and the appellees in United Building argued that White controlled, claiming that the union's privileges and immunities clause argument was "an Interstate Commerce Clause argument disguised as a Privileges and Immunities argument."8s

The Supreme Court, in an opinion by Justice Rehnquist, rejected this argument, however, noting,

The two Clauses have different aims and set different standards for state conduct.

The Commerce Clause acts as an implied restraint upon state regulatory powers. . . . When the state acts solely as a market participant, no conflict between state regulation and federal regulatory authority can arise. The Privileges and Immunities Clause, on the other hand, imposes a direct restraint on state action in the interests of interstate harmony. This concern with comity cuts across the market regulator-market participant distinction that is crucial under the Commerce Clause. It is discrimination against out-of-state residents on matters of fundamental concern which triggers the Clause, not regulation affecting interstate commerce. ${ }^{86}$

The Court thus refused to transplant the sovereign/proprietary distinction to privileges and immunities doctrine. ${ }^{87}$ The Court's rationale-that the privileges and immunities clause, for noneconomic reasons, directly restrains state activity-would also bar recognition of the

Bs 104 S. Ct. 1020 (1984).

84 Id. at 1023.

85 Brief for Appellees at 20, United Bldg. \& Constr. Trades Council v. Mayor of Camden, 104 S. Ct. 1020 (1984).

${ }^{88}$ United Bldg., 104 S. Ct. at 1028 (citations omitted).

87 Whether the Court will apply a special privileges and immunities clause analysis in relevant cases involving nonsovereign governmental activities remains to be seen. 
distinction in cases involving other constitutional provisions that so restrain state action, provisions such as the first amendment and the due process clause.

\section{Evaluating the Court's Distinction}

The governmental activity challenged in many of the cases just discussed differs from the traditional regulatory-type governmental activities with which the Court has historically been concerned. Governments today are engaged in very different types of activities than they were when the Framers drafted the commerce clause and the first amendment. ${ }^{88}$ For example, until about 1950 wages and salaries constituted the largest item in the United States government's budget. ${ }^{89}$ Since then, however, contract disbursements have been larger. ${ }^{90}$ Professor Lindblom suggests that this change "marks a shift from government reliance on authority or administrative direction (over its own employees) to market direction through purchases of final products from enterprises." The government has become a more direct participant in nonlabor and labor markets.

Governments have also recently begun to participate in revenueraising activities, such as the issuing of bonds. Although governments have long relied on user fees-stamps, for example-to generate revenue, their entry into the bond market is notable because it puts them in direct competition with private revenue-raising entities. ${ }^{92}$

The proliferation of public authorities ${ }^{\mathbf{2 3}}$ in the past fifty years is another example of the government's changing role in the private

${ }^{88}$ Professor Varat notes that there is "no indication that [the Framers] thought about state proprietary policy at all." Varat, supra note 3, at 505. However, he asks why traditional commerce clause analysis cannot be used to analyze state proprietary activities since in other areas the extent of the commerce clause power has changed dramatically since the Constitution was first adopted. The answer is that the emergence of state proprietary activities does not simply indicate a change in the extent of power under the commerce clause but rather signals government involvement in an entirely different type of activity, uncontemplated by the Framers, so that state proprietary activities actually conflict with the goals of the commerce clause or the balance of powers established by the Constitution.

${ }^{89}$ C. Lindbloom, Politics and Markets 111 (1977).

${ }^{80} \mathrm{Id}$.

91 Id. (citation omitted).

92 Stone, supra note 16 , at 1446 . Whether governments should engage in such activities is a different question. An argument can certainly be made for allowing voters to prefer such activities to higher taxes.

93 Public authorities are semi-autonomous government bodies that raise capital from the capital markets to invest in public facilities and services. "They are owned by the government that so establishes them, but they are hybrid creatures, possessing some of the characteristics of private firms and some of public agencies." A. WALSH, THE Public's Business 4 (1978). 
arena. One observer noted,

American government is in business in a big way. ... In the United States, for the most part, government enterprise involves public ownership without public policy.

Since the births of the Port Authority of New York and New Jersey in 1921 and the Tennessee Valley Authority in 1933, the most common form of government enterprise has been the public authority. . . They are one of the few popularly acceptable forms for American government to engage in economic activities. ${ }^{94}$

The relationship between the public and private sectors has changed in another way: private entities have entered markets that have been the traditional realm of government alone, such as postal service, hospital care, and education. For example, the first hospitals in the United States were public hospitals that were established as little more than almshouses for the care of persons who had nowhere else to go. Today, nonpublic hospitals provide most hospital care. ${ }^{95}$ Thus the nature of the market has changed completely. ${ }^{96}$ Similar changes may be occurring in the mail delivery and education markets. ${ }^{97}$

These changes in the relationship between the government and the private sector may have spurred the Court's development of the sovereign/proprietary distinction. ${ }^{98}$ However, though constitutional doctrine must evolve to reflect contemporary developments, the Court's application of the sovereign/proprietary distinction has been flawed.

The principal problem has been that, whereas the Court has clearly identified the two categories of governmental activity-sovereign and proprietary-to be distinguished, it has failed to elucidate a princi-

\section{Id. at 3.}

${ }^{85}$ See Rosenblatt, Health Care Reform and Administrative Law: A Structural Approach, 88 YALE L.J. 243, 249 n.16 (1978).

${ }^{96}$ Indeed, the federal government encouraged the building of private hospitals. See Rosenblatt, supra note 95, at 264-76. The establishment of a voucher system in health care-i.e., Medicaid-also encouraged private hospitals and physicians to provide health care to the poor.

${ }_{97}$ Cf. I. DE Sola Pool, Technologies of Freedom 75-79 (1983) (stating that in the American colonies, until the 1820's, "the post office was run with an eye to making money for the government" but noting that services such as rural delivery-introduced to effect social goals-were later introduced at the expense of profit).

${ }^{88}$ Judge Friendly's comment made in the state action context may be equally applicable here: "Particularly in these days when the state's activities embrace not only the fields traditional when the [Fourteenth] Amendment was adopted but higher education, health, transportation, power production, housing and many others, a principle that all Fourteenth Amendment guarantees apply to all institutions serving 'public purposes' is much too expansive." H. Friendly, The DarTmouth College CaSE and the Public-Private Penumbra 24 (1968). 
pled method by which courts may determine what governmental activity falls under which category. ${ }^{90}$ Without such a method judges may simply choose a particular label in order to reach a desired result.

A second problem is that the Court has failed to articulate any limits on the scope of the distinction's applicability; indiscriminate resort to the distinction could undermine important rights developed by two centuries of constitutional jurisprudence. Justice Rehnquist's advocacy of adoption of the sovereign/proprietary distinction in the first amendment context is illustrative of this concern. ${ }^{100}$

\section{THE MODEL}

\section{A. Assumptions}

Since the sovereign/proprietary language implies that economic factors distinguish different governmental activities, it is helpful to look to economics for guidance in distinguishing activities in which governments act as sovereigns from those in which they act as proprietors. The starting point of the liberal political economy is the premise that our society and legal system are based upon a mixed market economy. This means that our laws assume that individuals freely and rationally engage in economic activity in the pursuit of maximizing profit or personal utility and, indeed, ought to be encouraged to do so. Economic theories of the state assume that the state aims to maximize society's economic welfare. Market failures may result in a situation in which the price of a good does not reveal the true total of individual preferences-also known as "demand." When this happens, the government must correct the market failures in order to allow the market to

99 Professor Varat has suggested that lower court judges "may strain to choose the desired label and reach controversial results." Varat, supra note 3, at 507 n.84.

The Court of Appeals for the Seventh Circuit recently refused to label as proprietary an Illinois preference law that required all state public works contractors to employ only Illinois laborers. The court therefore scrutinized the law under standard commerce clause analysis and held it to be unconstitutional. See W.C.M. Window Co. v. Bernardi, 730 F.2d 486, 494-96 (7th Cir. 1984). Writing for the majority, Judge Posner stated that, had the state limited the preference to projects financed or administered by the state, its action would have been proprietary - and constitutional. See id. at 495 . However, Posner had some trouble distinguishing Supreme Court cases that had upheld state regulations that were arguably as broad as the Illinois law. See id. (discussing American Yearbook Co. v. Askew, 339 F. Supp. 719 (D. Fla.) (concluding that state statute that required all public printing be done within the state violated the commerce clause), affd mem. 409 U.S. 904 (1972)).

100 Another problem with recognition of the distinction in constitutional law is that there results a doctrinal inconsistency with antitrust law, where the distinction has not been used by the Court. See supra note 42. Justice Blackmun's assertion of "evenhandedness" as a rationale for the distinction in commerce clause cases applies equally well here. The Court's current doctrine allows states to have it both ways. 
work. ${ }^{101}$

The government's role is thus limited to correcting market failures by providing goods and facilitating trades. ${ }^{102}$ In this role the government facilitates cooperation among private economic actors; by requiring cooperation, it can provide goods that would not otherwise be provided or allow individuals to engage in activities in which they would otherwise not engage.

Therefore the government has a legitimate role in our free market system-to correct market failures. The three classic types of market failures requiring governmental intervention are public goods, externalities, and natural monopolies.

Public goods are goods that must be provided to everyone and from which everyone benefits. ${ }^{103}$ One person's enjoyment of the good does not decrease another person's enjoyment. No single individual has an incentive to provide the good because once it has been paid for everyone can use it without paying. Thus each person's incentive is to wait for someone else to provide the good. Examples of public goods are national defense and fire and police protection. ${ }^{104}$ Since individuals acting on their own will not provide public goods, the goods can be supplied only by forcing people to provide the goods collectively.

Externalities are the benefits or harms of an economic activity that accrue to individuals not engaged in the activity. ${ }^{108}$ Pollution is the classic example. Again, the problem is the absence of an incentive for any individual to reveal her preferences, for if others will bear the cost of the externality, that individual can benefit without paying. As a result, the true cost of the good that imposes the externality will not be paid, unless people organize to develop a solution, for example, by charging fees, paying for the externalities from everyone's money, or enlarging the jurisdiction to include the areas where the harm or benefit occurs. ${ }^{106}$ However, it is costly for individuals to obtain the informa-

101 J. Burkhead \& J. Miner, Public Expenditure 97 (1971).

102 Some economists argue that redistribution of wealth is also a proper role of government in a liberal political economy. See, e.g., R. TResCh, Public Finance: A Normative Theory $8-9$ (1981). The controversial issues of when and to what extent governments should redistribute wealth are beyond the scope of this Comment.

103 J. Burkhead \& J. Miner, supra note 101, at 27-32; M. Olson, The Logic of Collective Action 14-15, 35 (1965); Samuelson, The Pure Theory of Public Expenditures, 36 Rev. Econ. \& STAT. 387 (1954).

104 Public education, especially at the elementary and secondary school levels, is a public good in the sense that everyone in society benefits from an educated populace. However, the benefits to the public differ greatly from those that accrue to the individuals being educated, so public education looks more like an externality. See J. BuRKHEAD \& J. MINER, supra note 101, at 33.

${ }^{108} \mathrm{Id}$. at 105.

${ }^{108}$ E. Mills, Urban Economics 235 (1972). 
tion needed to do this and to communicate their preferences with accuracy. These are "transactions costs." When transactions costs are high, the market ceases to function efficiently and nonmarket solutions may be needed to reduce welfare loss. ${ }^{107}$ Thus, this is another classic sovereign function of government.

Natural monopolies exist when the average cost of a good decreases substantially as the quantity of goods increases; for example, as when the production of a good requires a large fixed cost to make the good initially available but only small additional costs to produce increased quantities of the good. ${ }^{108}$ Examples of natural monopolies might be sewage collection and treatment, rail transportation, and telephone service. A natural monopoly will result in a single firm that prices the good above marginal cost (the price of the good when the market is working efficiently) and produces goods in sub-optimal quantities. Government regulation could lower prices to marginal costs and force the firm to produce the optimal quantity. Again, governments are good mechanisms for bringing people together and forcing this cooperation. ${ }^{109}$

Whenever governmental activity involves public goods, externalities, or natural monopolies, it most likely is acting to correct a market failure. However, there are circumstances in which this may not be true. As discussed, nongovernmental entities have entered fields that historically have been occupied exclusively by governmental actors. The entrance of private parties suggests that a market failure that might once have required the governmental activity no longer exists; when this occurs, no genuine market failure exists.

\section{B. Outlining the Model}

This Comment argues that governments that act as sovereigns exhibit two characteristics. First, in this role they address market failures; governments as sovereigns serve as conduits or organizing mechanisms through which individuals obtain a good or engage in a transaction. This is the common function of elected bodies, such as legislatures and town councils.

The second characteristic of sovereign governmental action is that it is coercive. The Supreme Court has sometimes described coercive ac-

107 J. Burkhead \& J. Miner, supra note 101, at 106-07.

108 P. SAmuelson, Economics 484 (9th ed. 1973).

109 This does not mean that governments have to provide the good. After it extracts the up-front fee, the government may turn the provision of the good over to a private party that may provide the good, as it does with many public utilities and water systems. 
tivity as that which affects the "citizenry in general."110 This is correct in the sense that if everyone within the jurisdiction of the governmental entity must comply with the regulation or engage in the transaction the governmental action is coercive. Conversely, if individuals have a genuine choice about whether to engage in the governmental transaction, the government is not acting coercively.

The most coercive governmental activities are those in which citizens must participate and to which no alternative is available. Taxation, zoning, and operation of the criminal justice system are examples. $^{111}$ Less coercive governmental activities are ones to which nongovernmental alternatives are available. Examples include public education and public health systems, as the state requires all citizens to attend school and be vaccinated, and, although the government will provide education and health care, private actors also supply these services to those who prefer and can afford them.

This Comment proposes that courts treat governmental entities as sovereigns only if they are acting to correct a market failure and are doing so coercively. If either of these conditions is not met, the government should be deemed to be acting as a proprietor.

According to this approach, the most sovereign governmental activity is taxation. When taxing, the government serves as a conduit, and it acts coercively. The tax system assures citizen cooperation and participation in an activity in which no individual would have an incentive to engage in alone.

At the other end of the continuum would be state lotteries, which are intended only to raise money for the government. Here, the government is not correcting any market failure but is selling goods directly to buyers for a fee. Whether it is being coercive is less clear. Individuals are arguably free to buy a ticket or not, yet the government may have a monopoly over lottery tickets, a factor that implies coercion. ${ }^{112}$ Still, the citizen in the lottery ticket market is considerably freer than the citizen in the tax or public education market. Thus, when the government operates a lottery, it is probably not acting as a sovereign. ${ }^{113}$

110 See, e.g., Pickering v. Board of Educ., 391 U.S. 563, 568 (1968).

111 The only way not to participate would be to avoid all connection with the government. For example, one could avoid participation in the income tax system by avoiding work and other income-producing activity and divesting oneself of assets that produce income. Likewise, one could avoid property taxes by not owning property.

112 The difficult problem of defining the market is raised when the government enjoys a monopoly on lotteries in the state. For example if the market is defined as the lottery market (as opposed to, say, the entertainment market), then people who want to buy lottery tickets have to either buy them from the government or forego lottery tickets altogether. This problem of market definition is a common one in antitrust law.

113 Just as the private entrepreneur is judged by the purpose and character of her 
Most governmental activities fall somewhere between these two extremes. Courts using the analysis this Comment proposes will be able, in a principled way, to determine whether the government in a particular case is acting as a sovereign or as a proprietor. Unfortunately, the Supreme Court's efforts at such determinations have often been misdirected, as the following discussion reveals.

\section{G. Applying the Model}

\section{Commerce Clause Cases}

In Hughes v. Alexandria Scrap Corp., ${ }^{114}$ Maryland acted as a sovereign. First, it created the bounty scheme in order to remove an externality (abandoned cars) and to protect the state's environment and was thus was correcting a market failure. And by creating the market and, as a monopolist, barring voluntary schemes for the removal of abandoned cars, the stated acted coercively. The actual effect of the scheme was to create a government subsidy program, ${ }^{115}$ with a smaller amount paid for out-of-state goods. Because the state was addressing a market failure and because it was doing so coercively, it, according to the analysis proposed by this Comment, acted as a sovereign, and, contrary to the Court's holding, ${ }^{110}$ its action should have been scrutinized under traditional commerce clause analysis.

The status of the state whose action was challenged in Reeves, Inc. v. Stake ${ }^{117}$ is more difficult to determine. The initial decision to build and operate the cement plant came in response to a cement shortage and was a "product of the State's then-prevailing Progressive political movement."118 The state's action thus appears to have been directed at a market failure. Nonetheless, the cement market may have changed in the fifty years during which the state operated the plant so that no failure existed at the time the suit was brought; by that time the state may have been operating the plant solely because of its profitability.

enterprise regardless of the final disposition of the profits, so the government's economic activity ought to be judged without regard to the ultimate expenditure of the revenues.

114426 U.S. 794 (1976).

118 Accord Reeves, Inc. v. Stake, 447 U.S. 429, 440 n.14 (1980). Thus Maryland's program looks more like a subsidy of state residents than a tax on nonresidents. The latter appears to be impermissible if its effect is to create an economic barrier to interstate commerce. See, e.g., Dean Milk Co. v. City of Madison, 340 U.S. 349 (1951).

116 In Alexandria Scrap the Court held that Maryland's scrap bonus arrangement was a proprietary governmental activity and was thus exempt from commerce clause analysis. See supra text accompanying notes 29-35.

117447 U.S. 429 (1980).

118 Id. at 430 . 
Although it appears that the state was not a monopolist in the cement market, ${ }^{119}$ the record does not make clear whether the state's power was still coercive. Thus, if the government was acting in response to a market failure rather than, for instance, to make money and if it was acting as a coercive entity in the market, the exclusion of outof-state buyers should have been analyzed under traditional commerce clause analysis. Once again, this analysis suggests a result contrary to that reached by the Court. ${ }^{120}$

Finally, the city of Boston in White v. Massachusetts Council of Construction Employers, ${ }^{121}$ was acting as a proprietor because it was not regulating or monopolizing the Boston building construction market and thus was exercising only limited coercive power. And the government was not acting as a conduit for cooperation but as an employer of labor. Thus the analysis proposed here supports the Court's conclusion that the Boston ordinance should be exempt from standard commerce clause analysis.

\section{Non-Commerce Clause Cases}

Board of Education, Island Trees Union Free School District No. 26 v. Pico, ${ }^{122}$ Lehman v. City of Shaker Heights, ${ }^{123}$ and United Building and Construction Trades Council v. Mayor of Camden ${ }^{124}$ all reveal an important limitation inherent in the sovereign/proprietary distinction: it is not a useful tool for assessing the role of government in noneconomic contexts. In neither Pico nor Shaker Heights was there a majority opinion adopting the distinction in first amendment doctrine, and a majority of the Court rejected extension of the distinction to privileges and immunities doctrine in United Building.

Shaker Heights illustrates nicely the problem that arises when the distinction is applied unthinkingly in a noneconomic context. When the Court said that the city bus was more like a newspaper than a park, surely it did not mean that what is acceptable behavior for Rupert Murdoch is equally acceptable for the city of Shaker Heights. The latter ought to be held to a higher level of constitutional behavior, for when the government acts, it puts its "seal of approval" on a certain

119 See id. at 432.

120 In Reeves the Court held that the state's cement production was a proprietary activity and thus that the state's preferential treatment of in-state cement customers was exempt from traditional commerce clause analysis. See supra text accompanying notes 29-34.

121460 U.S. 204 (1983).

122457 U.S. 853 (1982) (plurality opinion).

123418 U.S. 298 (1974) (plurality opinion).

124104 S. Ct. 1020 (1984). 
type of behavior, an important effect not considered in a sovereign/ proprietary discourse.

Or consider state operation of a lottery. Suppose that the state, to generate revenue, permits advertisements on the back of lottery tickets and that the Republican state administration refuses to sell space to businesses owned by Democrats. If the courts treated the state that operated such a lottery as a proprietor, the state would not be subject to first amendment scrutiny, and it would thus be free to discriminate. Yet allowing such behavior by the government would be terribly wrong, for the state has, in effect, sanctioned two-class citizenship and has raised the first amendment rights of one group above those of another. It is clear that the Court would hold that such action violated the first amendment. Even Justice Rehnquist concedes this. ${ }^{125}$

These examples illustrate the problems that arise when the sovereign/proprietary distinction is applied in non-commerce clause cases. Because the distinction is rooted in the differing economic consequences attributable to different governmental activities, it ignores the noneconomic effects of governmental behavior, effects that are central to many areas of constitutional analysis, such as the first amendment. The commerce clause, in contrast, is primarily concerned with the economic impact of governmental action on interstate commerce and the national economic unit. ${ }^{12 B}$ The sovereign/proprietary distinction is therefore most useful in commerce clause cases.

The Court's recent decision in United Building indicates that it recognizes this limit. In refusing to invoke the distinction there, the Court argued that, unlike the commerce clause, the privileges and immunities clause's "concern with comity cuts across the market regulator-market participant distinction that is crucial under the Commerce Clause. It is discrimination . . . which triggers the Clause, not regulation affecting interstate commerce."127 The same thing, of course, can be said of the first amendment.

\section{CONCLUSION}

The Supreme Gourt's reliance on the sovereign/proprietary distinction may be a legitimate attempt to respond to the changing functions of government. Over the past 200 years governments have, in many ways, evolved from lawmaker-regulators to suppliers of goods

${ }^{125}$ See Pico, 457 U.S. at 907-08 (Rehnquist, J., dissenting).

128 G. Gunther, Gonstitutional Law 113 (10th ed. 1975); J. Nowack, R. Rotunda \& N. Young, Constitutional Law 144-46 (2d ed. 1983).

${ }^{127}$ United Building, 104 S. Ct. at 1028. 
and services, a change that often has brought them into direct competition with the private sector. To the extent the distinction accurately reflects this change, it can be a useful tool. However, the Court's use of the distinction has been ad hoc and unprincipled, and, consequently, certain governmental activities have escaped commerce clause analysis that courts should have applied to them. Furthermore, the use of the distinction in areas such as the first amendment may be undesirable because it focuses the Court's attention on the coercive effect of the government in the economic market but ignores the special imprimatur that is put on all governmental activities.

This Comment proposes a principled method for distinguishing governments that act as sovereigns from those that act as proprietors: if a government acts as a collective mechanism to correct a market failure and does so coercively, it acts as a sovereign; otherwise, it acts as a proprietor. Use of this test will make more meaningful the application of the sovereign/proprietary distinction in commerce clause cases and will provide more guidance to lower courts and governments than does the Court's current approach. Yet it must be recognized that the distinction is not helpful for assessing the constitutionality of governmental action in non-commerce clause contexts, for it fails to take into account important noneconomic effects of governmental action. It should thus not be used in non-commerce clause cases. 